\title{
Renewable Energy Sources in Transport on the Example of Methyl Esters and Bioethanol
}

\author{
Adam Kupczyk, Joanna Mączyńska-Sęczek, Ewa Golisz (D) and Piotr F. Borowski *(i) \\ Institute of Mechanical Engineering, Warsaw University of Life Sciences, 166 Nowoursynowska Str., \\ 02-787 Warsaw, Poland; adam_kupczyk@sggw.edu.pl (A.K.); joanna_maczynska@sggw.edu.pl (J.M.-S.); \\ ewa_golisz@sggw.edu.pl (E.G.) \\ * Correspondence: piotr_borowski@sggw.edu.pl or pborowski@autograf.pl
}

Received: 10 November 2020; Accepted: 3 December 2020; Published: 7 December 2020

\begin{abstract}
The aim of this article is to show how the situation of domestic biofuels in Poland and the alternative fuels sector is changing. On the basis of our own research and the available literature, changes in the production potential of Poland in the field of alternative fuels/biofuels are examined. Moreover, the reasons for changes in the production structure are analyzed. The flexibility of production potential to changes in legal conditions is assessed, and the value of sectors and their future are determined. This paper discusses legal and market aspects related to selected renewable energy sources used in Polish transport. Based on a review of literature and statistical data, the production and use of methyl esters and bioethanol are characterized in detail. Analysis of legal regulations enables the presentation of targets regarding renewable energy source (RES) use in transport by 2030. The results of studies conducted in 2020 are discussed with regard to the value (attractiveness) of methyl esters, bioethanol, electromobility and liquid bio-hydrocarbons, and these are compared and contrasted with the result from earlier years since 2010.
\end{abstract}

Keywords: renewable energy sources; esters; processes; eco-mobility; $\mathrm{CO}_{2}$ emission reduction, mechanical engineering

\section{Introduction}

The transport sector plays a vital role in the economy. At the same time, it has a negative effect on the natural environment [1]. The energy consumed for transport purposes comes in a majority of cases from petroleum, which leads to a decline in natural fuel resources and to the emission of greenhouse gases in significant amounts [2-4]. Transport-related emissions come first and foremost from the direct combustion of fuels used in road transport, non-electrified railway transport and inland sailing [5]. Reducing emissions in road transport can also be implemented in parallel by using appropriate road surfaces [6,7]. Limiting the negative effects of transport is a significant component of the policy of the European Union (UE) and one of the chief actions taken in this area is the imposition among member states to use renewable energy sources (RES) for transport purposes [8]. The research undertaken in this study aimed to identify areas of development and dysfunction in the field of domestic alternative fuels. The research was carried out as a continuous monitoring of the sector, mainly on the basis of the point value (attractiveness) method of sectors, according to Porter's five forces [9]. After joining the EU in 2004, Poland planned a strong expansion of its own transport biofuels into the various EU markets. Conventional transport biofuels were expected to have many advantages, including reducing the emission of greenhouse gases. However, aspects that undermine their ecological character, such as the real reduction of greenhouse gas emissions and problems with achieving the assumed target (the national index target (NIT)), caused a significant increase in the importance of other alternative fuels as well. In Poland, the obligation has been fulfilled mostly by using methyl esters 
and bioethanol [10]. Before World War II, Poland used industrial ethanol as an additive to gasoline (approx. 10 million liters). In the 1970s, the technology for the production of lignocellulosic ethanol from wood waste was developed, whereas in the 1990s it was planned to implement bioethanol and gasoline blending technologies [11]. After Poland joined the EU, the industry was built from scratch, using the existing capacity for bioethanol and biodiesel production. Despite the expansion of plants in this sector, Poland's position was not favorable because of problems with the achievement of index targets and use of the existing production capacity began to occur. Production was based on imported technologies, but unfortunately these technologies were already in the mature phase, which resulted in a quick transition to a declining phase. As a result of investing in declining technologies, the benefits of their exploitation systematically decreased, and it provided less opportunities for development or meeting increasingly restrictive legal conditions in these sectors [12].

\section{Literature Review}

\subsection{Legal Grounds at the European Union Level}

The EU legislature, in the area of RES, has evolved substantially over recent years. Currently, the most important legal regulations stimulating the increase in use of RES includes Directives 2009/28/EC (referred to as RED) [13], 2015/1513 [14] and 2018/2001 (referred to as RED II) [15]. These directives bind the member states in terms of targets to be met, leaving them with freedom of choice as regards to the form and means of their accomplishment. The specification of the most important obligations resulting from these directives is presented in Table 1.

Table 1. Specification of the most important obligations resulting from the directives in the scope of use of renewable energy sources (RES) in transport for member states of the European Union.

\begin{tabular}{cc}
\hline Directive Name & Target for RES Use in Transport \\
\hline Directive 2009/28/EC (RED) & Min. 10\% share of renewable energy in end use of energy in transport in 2020 \\
Directive 2015/1513 & Max. 7\% share of conventional biofuels in the target set for 2020 \\
Directive 2018/2001 (RED II) & Min. 14\% share of renewable energy in end use of energy in transport in 2030 \\
& (including but not limited to 3.5\% advanced biofuels, max. 7\% conventional biofuels) \\
\hline
\end{tabular}

RED set a target ensuring a 10\% share of energy from renewable sources in transport by 2020 . Initially, biofuels (RED defines biofuels as liquid or gaseous fuels for transport produced from biomass) produced from food and feed plans-i.e., the so-called conventional biofuels-were mostly used for this purpose. For a long time, fuels of this sort were regarded as an effective means of emission reduction [16]. However, their perception changed over time and analyses showed that the production of such biofuels may entail indirect negative consequences as well [4]. The current results of studies on the value of biofuel sectors in Poland do not encourage investment in biofuels of this generation, i.e., conventional biofuels [17]. It has been observed that the growing demand for raw materials for the production of methyl esters and bioethanol (the most widely used biofuels), such as rapeseed or corn, is a form of competition for foodstuff and feedstuff markets [18]. If grasslands or farmlands previously used for the needs of those markets are adapted for the production of biofuels, it may be necessary to move the first type of production (for food purposes) to other lands, which are not farmlands. This phenomenon is known as indirect land use change (ILUC) which, when related to the transformation of lands rich in coal, can lead to considerable greenhouse gas emissions [14]. In order to minimize the effects of indirect land use change, in the target set for 2020 it was proposed to reduce the share of the biofuels produced from oleaginous, sugar and cereal crops, as well as other high-starch crops to max. 7\%. This modification was implemented with Directive 2015/1513. Concurrently, the directive commenced a period of promotion of the so-called advanced biofuels (advanced biofuels are defined as biofuels produced from the raw materials listed in Part A of Annex IX to Directive 2015/1513/EC or the raw materials listed in the national legislation), i.e., biofuels not competing with food producing crops (made of waste or algae, for instance) [19]. Such biofuels allow for the reduction 
of greenhouse gas emissions and, at the same time, are characterized by a low risk of indirect land use change [20].

The last of the mentioned directives, RED II, obliged the member states to ensure at least a $14 \%$ share of renewable energy in the end energy consumption in transport by 2030, provided that the share of advanced biofuels does not fall below 3.5\%. Maintaining the limit imposed by Directive 2015/1513, RED II stipulates that the share of conventional biofuels in the target set for 2030 in the given member states cannot exceed their share in 2020 by more than $1 \%$, and that the maximum share can be $7 \%$.

\subsection{National Legislature in the Scope of RES in Transport}

The member states are obliged to transpose (implement) the said directives into their internal legal systems. In Poland, the provisions of RED and Directive 2015/1513 are transposed into the national legislation mostly under the relevant act relating to biocomponents and liquid biofuels, which is amended on a regular basis [21]. RED II is to be transposed in 30 June 2021.

For the purposes of further discussion, it is necessary to quote the statutory definitions of "liquid biofuels" and "biocomponents". Liquid biofuels are defined as "engine gasoline containing over 10\% of biocomponents in volume; diesel oil containing over $7 \%$ of biocomponents in volume; bioethanol, ester, liquid bio-hydrocarbons-being independent fuels." The notion of biocomponents encompasses such substances as bioethanol, ester and liquid bio-hydrocarbons, which are "produced from biomass for the purpose of producing fuels, excluding other renewable fuels" [22].

To enable the accomplishment of the target set for 2020 in the scope of the share of renewable energy in transport, the so-called National Index Target (NIT) was established. It aimed to increase RES use in transport on a gradual, systematic basis. Under the act, NIT is defined as "the minimum share of other renewable fuels and biocomponents found in fuels used in all types of transport in the overall amount of liquid fuels and liquid biofuels consumed during a calendar year in road and railway transport, calculated according to the calorific value" [21]. For 2020, the NIT was set at 8.5\% [22]. The NIT obligation is one of the mains instruments of realization of the target set by RED. In addition to this obligation, the target is being accomplished mostly by use of renewable electric energy in transport [23].

Implementing the provisions of Directive 2015/1513, the discussed act stipulates that the share of conventional biocomponents, i.e., those made of high-starch, sugar and oleaginous crops and crops cultivated for energy purposes on farmlands (as main crops), in the fuels used in transport cannot exceed $7.0 \%$ of the overall quantity of liquid fuels and biofuels used in road and railway transport in 2020. As mentioned in the previous subsection, the said directive led to a period of advanced biofuel promotion. In some countries, including Poland, such biofuels-as well as biofuels produced from used cooking oil or animal fats-are double-counted for realization of the targets set with regard to the use of renewable energy in transport [24]. Under the national legislation, the share of advanced biocomponents in fuels in 2020 cannot be less than $0.1 \%$ of the quantity of liquid fuels and biofuels used in road and railway transport [21].

\section{Materials and Methods}

\subsection{Production and Use of Biocomponents in Poland}

As mentioned above, the EU-imposed obligation regarding the minimum share of renewable energy in Polish transport in 2020 is satisfied mainly by way of the use of methyl esters and bioethanol [10]. Liquid bio-hydrocarbons are also used as biocomponents, but in considerably lower quantities.

Fatty acid methyl esters (FAMEs) are produced based on vegetable oils, e.g., rapeseed oil or used cooking oil [25]. Bioethanol is a dehydrated ethyl alcohol produced from biomass or waste, containing monosaccharides or polysaccharides [20]. Liquid bio-hydrocarbons are liquid hydrocarbons produced from biomass, including hydro-refined oils, e.g., fuels of the hydrogenated vegetable oil (HVO) type, [21], which are raw materials of great potential [26]. 
In Poland, the basic raw material used to produce methyl esters is rapeseed oil. In 2019, it was used in a quantity of $869 \mathrm{kt}(1 \mathrm{t}=1000 \mathrm{~kg})(90 \%$ of all raw materials). The production of bioethanol is dominated by corn, which was used in a quantity of $512 \mathrm{kt}$ (48\%) [27]. Both rapeseed oil and corn are foodstuff raw materials that are in competition for foodstuff and feedstuff markets; thus, the biocomponents produced from them are not eligible for double-counting in terms of NIT realization. However, Polish producers have been using more waste raw materials (eligible raw materials) since 2018 [28]. In 2019, the share of that sort of raw materials in the overall quantity of raw materials used to produce methyl esters was $11 \%$, and it was $28 \%$ in the overall quantity of raw materials used to produce bioethanol [27]. In the production of liquid bio-hydrocarbons in Poland, the prevalent raw material used is ethyl alcohol of agricultural origin (58\% of all raw materials), which makes the biocomponents produced from it eligible for double-counting for the purposes of NIT realization.

The overall annual performance of the installations used to produce methyl esters in Poland as of 25 September 2020 was $1.52 \mathrm{k}\left(\mathrm{m}^{3}\right)$, to produce bioethanol- $0.9 \mathrm{k}\left(\mathrm{m}^{3}\right)$, and biohydrocarbons- $0.25 \mathrm{k}\left(\mathrm{m}^{3}\right)$ [29]. Having recalculated the declared production capacities expressed in volumetric units per mass units (using the biocomponent density, calculated on the basis of data regarding calorific values specified in the Regulation of the Minister of Economy of 21 October 2014 on calorific value of specific biocomponents and liquid fuels (Journal of Laws of 2014, item 1517)) and having analyzed the data on the quantities of produced biocomponents (Table 2), it turns out that the production capacities of Polish producers are not utilized at $100 \%$, which a phenomenon that has been observed in Poland for many years [30]. In the case of bioethanol producers in the period from 2010 to 2018 , their production capacities were utilized at $28 \%$ on average; in the case of methyl ester producers it was $62 \%$ [31].

Table 2. Quantity of raw materials used and biocomponents produced using them in Poland in 2019 (kt).

\begin{tabular}{|c|c|c|c|c|c|}
\hline \multirow[t]{2}{*}{ Type } & \multirow[t]{2}{*}{ Raw Material } & \multicolumn{2}{|c|}{$\begin{array}{c}\text { Quantity of Raw Material Used } \\
(\mathbf{k t})\end{array}$} & \multicolumn{2}{|c|}{$\begin{array}{l}\text { Quantity of Biocomponent } \\
\text { Produced (kt) }\end{array}$} \\
\hline & & (1) & (2) & (1) & (2) \\
\hline Methyl ester & $\begin{array}{l}\text { Rapeseed oil } \\
\text { other }\end{array}$ & $\begin{array}{c}869.36 \\
10.49\end{array}$ & 85.02 & 877.14 & 83.00 \\
\hline Bioethanol & $\begin{array}{c}\text { corn } \\
\begin{array}{c}\text { Soybean waste suspension } \\
\text { other }\end{array}\end{array}$ & $\begin{array}{l}511.50 \\
228.59\end{array}$ & $\begin{array}{c}276.59 \\
16.83\end{array}$ & 213.04 & 12.41 \\
\hline $\begin{array}{c}\text { Liquid } \\
\text { bio-hydrocarbons }\end{array}$ & $\begin{array}{c}\text { Ethyl alcohol of agricultural origin }{ }^{(4)} \\
\text { other }\end{array}$ & 0.01 & $\begin{array}{l}0.07 \\
0.04\end{array}$ & 0.01 & 0.05 \\
\hline
\end{tabular}

Table 3 illustrates the balance of methyl esters and bioethanol in Poland from 2010 to 2018. According to the data published by Statistics Poland, at the end of the analyzed period the production of methyl esters $(888.9 \mathrm{kt})$ was more than twice as high compared to the beginning of the period $(379.8 \mathrm{kt})$. The national consumption grew slightly by $33.5 \mathrm{kt}$. The volume of import of that biocomponent declined by $80.1 \mathrm{kt}$. The comparison of import and domestic production is notable. Initially, in 2010, more methyl esters were imported than were produced domestically. At the end of the analyzed period, imports accounted for $36 \%$ of their production. Within the analyzed period, exports of methyl esters increased significantly year-to-year and reached $797.3 \mathrm{kt}$ in 2016, which is over sixty times higher compared to 2010. Production of bioethanol in 2010-2018 increased as well, but the increase was not as significant as in the case of methyl esters (i.e., by $33.5 \mathrm{kt}$ ). Imports of this biocomponent decreased almost twice (from 118.0 thousand $\mathrm{t}$ in 2010 down to $59.96 \mathrm{kt}$ in 2018) and its consumption decreased as well, by $23.3 \mathrm{kt}$. 
Table 3. Balance of methyl esters and bioethanol in Poland in 2010-2018 (kt).

\begin{tabular}{|c|c|c|c|c|c|c|c|c|c|}
\hline & 2010 & 2011 & 2012 & 2013 & 2014 & 2015 & 2016 & 2017 & 2018 \\
\hline \multicolumn{10}{|c|}{ Methyl Esters } \\
\hline Domestic production & 379.80 & 363.89 & 605.39 & 642.37 & 739.01 & 788.24 & 900.51 & 899.31 & 888.90 \\
\hline Import & 397.69 & 495.63 & 181.39 & 156.22 & 129.88 & 189.30 & 216.65 & 310.15 & 317.50 \\
\hline Export & 13.06 & 37.44 & 48.51 & 157.98 & 235.04 & 420.17 & 797.27 & 753.32 & 393.19 \\
\hline Inventories change & -3.47 & 1.37 & -8.37 & 19.92 & -2.90 & -11.93 & -7.98 & -0.62 & -18.81 \\
\hline Domestic use & 760.96 & 823.45 & 729.90 & 660.52 & 630.95 & 545.44 & 311.90 & 455.52 & 794.41 \\
\hline \multicolumn{10}{|c|}{ Bioethanol } \\
\hline Domestic production & 152.80 & 136.58 & 172.53 & 190.92 & 142.79 & 173.93 & 195.37 & 190.63 & 186.32 \\
\hline Import & 118.03 & 120.06 & 43.83 & 41.16 & 64.20 & 65.68 & 69.02 & 70.10 & 59.96 \\
\hline Export & 1.45 & & 1.9 & 2.73 & 2.19 & 2.33 & 2.95 & 10.15 & 1.74 \\
\hline Inventories change & -3.09 & -4.83 & 2.48 & -3.04 & 1.21 & 0.72 & -1.44 & -3.24 & -1.28 \\
\hline Domestic use & 266.29 & 251.81 & 216.94 & 226.31 & 206.01 & 238.00 & 260.00 & 247.33 & 243.26 \\
\hline
\end{tabular}

\subsection{Assessment of the Level of Fulfilment of EU Obligations and Challenges of the Near Future}

Under RED, the member states, including Poland, were obliged to achieve at least a $10 \%$ share of renewable energy in end energy consumption in transport in 2020. In 2018, Poland demonstrated a share of 5.6\%, which was lower by 1 percentage point than in 2010 (Table 4).

Table 4. Share of renewable energy in Polish transport in 2010-2018 (\%).

\begin{tabular}{cccccccccc}
\hline Year & $\mathbf{2 0 1 0}$ & $\mathbf{2 0 1 1}$ & $\mathbf{2 0 1 2}$ & $\mathbf{2 0 1 3}$ & $\mathbf{2 0 1 4}$ & $\mathbf{2 0 1 5}$ & $\mathbf{2 0 1 6}$ & $\mathbf{2 0 1 7}$ & $\mathbf{2 0 1 8}$ \\
\hline Share (\%) & 6.6 & 6.8 & 6.5 & 6.6 & 6.2 & 5.6 & 3.9 & 4.2 & 5.6 \\
\hline \multicolumn{8}{c}{ Source: own study based on [35]. }
\end{tabular}

To a great extent, the reduction in the share of renewable energy in Polish transport-apparent in 2015 and considerably deepening in 2016-resulted from a significant increase in fuel consumption, which was a consequence of activities aiming at limitation of the functioning of the so-called gray market. There resulted, inter alia, an increase in the official use of diesel oil, from 11.5 million $\mathrm{t}$ in 2015 to 17.2 million $t$ in 2018 and an increase in its imports from 1 million $t$ to 4.7 million $t$ [36]. Along with the limitation of the gray market and the increase in the use of conventional fuels, the issue of ensuring proper quantities of biocomponents intensified. Their share in 2020, according to the set level of the national index target, was to be $8.5 \%$.

According to the list kept by the President of the Energy Regulatory Office (status as of 4 October 2020), 16 entities in Poland are obliged to meet NIT [37]. Due to the fact that the sector of liquid fuel production and liquid fuel imports or intra-community purchase is characterized by high concentrations, an analogous situation occurs in the entities pursuing the national index target. As a result, PKN Orlen S.A. (Płock/Warsaw, Poland) and Grupa Lotos S.A. (Gdańsk, Poland) are the entities responsible for its realization, with a contribution of ca. 85\% [36].

Although using fatty acid methyl esters and bioethanol are the most common method to meet the commitments resulting from RED in Poland, due to numerous limitations (including technical barriers, the so-called blending wall, which limit their use in liquid fuels down to standard E5/E10 and B7 [23]) and the current market situation, the NIT level that can be achieved with them does not exceed $6 \%$ [23]. Therefore, it is estimated that in order to reach the level of $8.5 \%$, it is necessary to use ca. $700 \mathrm{kt}$ of liquid bio-hydrocarbons in transport (ca. $500 \mathrm{kt}$ produced from foodstuff raw materials and 170-190 kt produced from raw materials eligible for double-counting). In the case of bio-hydrocarbons, there is no blending wall issue, and they can be added to liquid fuels in excess of the standards effective for esters and bioethanol [23].

In addition to the most commonly used esters and bioethanol, the NIT can also include bio-hydrogen produced using biomethane, as well as products of co-hydrogenation [38]. This process 
consists in co-hydrogenation of petroleum derivative fractions with vegetable oils or animal fat, allowing the output of a product containing a high-quality biocomponent.

At present, biomethane utilization for fulfilment of the obligations regarding RES in transport is low (below $1 \%$ of all biocomponents). However, it is seen as a promising direction [23], taking into account the potential of the raw materials from which it can be produced and which are eligible for assignment to the advanced biofuel category [15]. It is estimated that the demand for biomethane for biohydrogen production may reach the level of ca. 700 million $\mathrm{m}^{3}$ [23]. Co-hydrogenation is a process which consists in simultaneous hydro-refining of biomass and the fractions from petroleum refining and which results in the formation of liquid bio-hydrocarbons and bio-propane in a mixture with hydrocarbons from petroleum refining [38].

\subsection{Sector Value Studies}

In this study, we used a method of number scoring to determine the value of a sector [39]. This method is classified as a qualitative method [40]. It was based on the assumption that properly selected criteria (factors) determine the attractiveness of the assessed economic field [41,42]. The scoring method was used because it enables a multi-criteria, weighted comparative assessment of several sectors and is a method verified by the authors [17]. It makes it possible to assess the development/decline of sectors over the years and allows for analysis in the future. By assessing the value of a sector, we can determine its structural features. Selected criteria, properly adapted to the analyzed sectors, are evaluated on a $0-3$ scale (depending on the intensity of their occurrence). Each factor is given the appropriate weight. The use of weighted assessments occurs due to the different importance of individual factors, as some of them may have a higher or lower influence on the assessment of the sector. Using an identical set of criteria, one can compare and contrast any number of sectors. In the studies considered, each sector was evaluated by means of the so-called grade matrix, containing 15 identical factors each from the group of market, financial, technical and organizational criteria (such as sector size and its expected growth rate, raw material availability, price level, competition strength, risk of substitution or favoring of European Union policy). The result of assessing the sectors is a ranked list, presenting the sectors from the most valuable to the least valuable. The assessment was carried out by sector experts, i.e., persons having extensive knowledge in this area of study.

The value of the sector of biocomponents, such as methyl esters and conventional bioethanol (produced from raw foodstuff materials) has been studied since 2007. Moreover, in 2013-2018 the scope of studies covered advanced bioethanol, produced from lignocellulose. As of 2018, evaluation has also been carried out on the sector of electric energy used in transport (electromobility) and since 2019-the sector of liquid bio-hydrocarbons.

Our studies omitted the sector of bioethanol (a subsector) based on ethyl alcohol of agricultural origin (two-phase production) produced in Polish agricultural distilleries. Since joining the EU, the significance of those sectors has been marginalized due to low price competition, the lack of economies of scale and environmental aspects (no $\mathrm{CO}_{2}$ emission reduction). A series of factors led to a decrease in the number of agricultural distilleries from ca. 1000 operating after World War II to several dozen operating nowadays, with organizations representing them currently winding up operations, e.g., the Association of Polish Distilleries in 2020.

The table below (Table 5) presents the 2020 results, compared with 2010-2019 results.

At the beginning of the studied period, the sectors of conventional methyl esters and bioethanol were characterized by relatively high attractiveness. Producers could use different forms of investment support or excise duty reliefs-the market was soaking products up and growing. At the time, the value of those sectors was under the influence of domestic and EU demand (opportunities for exporting Polish biocomponents), favorable legal conditions in the EU and beneficial forecasts, as well as legal conditions and political support at the domestic level. Over time, however, the attractiveness of those sectors declined, which was a result of different economic, political, legal, technological or environmental factors. 2011 witnessed the disappearance of beneficial excise duty reliefs and it turned 
out that, according to the adopted $\mathrm{CO}_{2}$ emission reduction methodology, the achieved value was not sufficient with regard to these fuels. In consequence, the need arose (entailing costs) to properly adapt the operating installations and technologies for the production of these biocomponents, so that the $\mathrm{CO}_{2}$ emission reduction could be boosted. The current capacities, according to the studies, in terms of esters and bioethanol will be tolerated by ca. 2030; after 2035 they will either be transformed (direction seeking) or enter a clear decline phase.

Table 5. Obtained study results regarding the values of selected Polish sectors of biocomponents and electric energy used in transport in 2010-2020 (\%).

\begin{tabular}{cccccccccccc}
\hline Assessed Sector & $\mathbf{2 0 1 0}$ & $\mathbf{2 0 1 1}$ & $\mathbf{2 0 1 2}$ & $\mathbf{2 0 1 3}$ & $\mathbf{2 0 1 4}$ & $\mathbf{2 0 1 5}$ & $\mathbf{2 0 1 6}$ & $\mathbf{2 0 1 7}$ & $\mathbf{2 0 1 8}$ & $\mathbf{2 0 1 9}$ & $\mathbf{2 0 2 0}$ \\
\hline Convention methyl esters & 58.3 & 53.3 & 43.2 & 41.7 & 34.5 & 33.5 & 33.4 & 32.1 & 31.6 & 31.5 & 32.0 \\
Conventional bioethanol & 44.2 & 43.3 & 33.3 & 37.5 & 27.3 & 26.7 & 26.6 & 22.8 & 22.3 & 24.0 & 25.0 \\
Lignocellulosic bioethanol & & & & 56.9 & 66.2 & 66.2 & 69.5 & 70.6 & 71.1 & & \\
$\quad$ Electrical energy & & & & & & & & & 70.6 & 72.5 & 65.0 \\
Liquid bio-hydrocarbons & & & & & & & & & & 58.3 & 61.2 \\
\hline
\end{tabular}

Source: Own study. Results from prior years published in [17,43-46].

Lignocellulosic bioethanol was intended to come to the rescue of the market needs and requirements regarding $\mathrm{CO}_{2}$ emission reductions-for a short time, the sector was seen as very promising, thanks to which it achieved the peak value. However, the situation was reversed. Studies on the production of lignocellulosic bioethanol usually ended at the pilot stage and the costs of its production were not accepted by the market. The production of lignocellulosic bioethanol is quite complicated due to the complex structure of raw materials. The best effects are achieved when wooden raw material is used with specific repeatable features, i.e., raw material from crops (crops mean increased energy expenditures and limited $\mathrm{CO}_{2}$ emission reduction, as well as the need for available farmland). With relatively high $\mathrm{CO}_{2}$ emission reductions, production costs were the main barrier. Currently, interest in this biocomponent is marginal.

Electromobility is a new sector with has given rise to hopes and an unquenched demand in Europe, including Poland [47]. Electric vehicles are being refined so as to bring their features (e.g., reach or driving time as well as mechanical strength) closer to conventional vehicles [48]. The issue of charging battery-powered vehicles is significant as well [49]. Electric vehicles are often referred to as zero-emission vehicles, although this is sometimes challenged. Taking into account the source of electric energy, often with high emissions (a network of "carbon" energy), the actual $\mathrm{CO}_{2}$ emission reduction for the electric car may not be so high. According to political announcements, the sector will be developed intensively and in 2030 electromobility is to account for a considerable portion of renewable energy in transport. Electromobility makes sense and has a positive effect on the environment when it is based on electric energy from RES [50].

Therefore, it is important that energy production does not contribute to the increase in pollutant emissions [51,52]. The problems of climate change and air pollution necessitate the search for new, ecological, widely available and efficient methods of energy production. Leading the way in this respect is renewable energy using wind, sun, water and biomass resources. Therefore, alternative raw materials and energy materials to coal should be sought. One of these solutions may be the use of renewable biomass from bamboo instead of the previously used wood biomass [53,54]. Another solution may be technologies for converting waste into energy, from the use of digestate from a biogas plant cooperating with a sewage treatment plant [55].

The sector of liquid hydrocarbons is a new sector, studied since 2019. Hydrocarbons, the substrates of which are organic waste products, demonstrate high $\mathrm{CO}_{2}$ emission reductions and can significantly contribute to meeting the targets set by RED and RED II. The sector is characterized by value growth, and the biocomponent in question is gaining ground, but is nonetheless of little significance as yet. The sector of liquid bio-hydrocarbons enjoys legal support, a market pull-selling phenomenon and very good forecasts. 


\section{Results}

Poland has a long tradition in the use of alternative fuels. After World War I it used industrial ethanol for mixing with gasoline, in the 1970s wood waste was utilized to form lignocellulosic ethanol, and in the 1990s, technologies for blending bioethanol with gasoline were developed.

As regards the target of achieving at least $10 \%$ renewable energy in end energy consumption in transport in 2020 (which is to grow to 14\% in 2030), as well as to limit the share of conventional biofuels (max. $7 \%$ ), Poland is facing quite a challenge.

There are high penalties for failing to achieve the required indicators. Moreover, the methods of calculating indicators have been modified to their detriment (the support for advanced technologies was reduced). The interest of the EU in promoting bioethanol and esters will actually end after 2030, when all support and promotion measures for this sector will be abolished.

According to the position of the Ministry of Energy (ME) from 2016, the achievement of 8.5\% NIT was to allow realization of the EU commitment and the electric energy used in transport was to supplement it [56]. In reality, however, the entities pursuing NIT have managed to achieve only ca. $5.5-6 \%$ [57] and electromobility, due to insufficiently widespread infrastructure, is still a thing of the future [58].

Currently, Poland does not have any RES sector for transport with major market significance, high production capacities and high $\mathrm{CO}_{2}$ emission reduction potential. Admittedly, sectors of conventional biocomponents offer high production capacities, but their potential is not utilized to the fullest due to technical limitations. The value and competitiveness of these sectors is steadily on the fall, considering the EU policy that is unfavorable to raw materials used in their production, as well as low $\mathrm{CO}_{2}$ emission reductions. The sector of lignocellulosic bioethanol, which initially gave rise to high hopes, does not function in the market reality.

\section{Conclusions}

After Poland's accession to the EU, it turned out that the bioethanol industry did not play its intended role, and investments in bioethanol were initiated (single-phase plants). Despite playing a significant role in the initial phase (Poland initially met relatively low requirements, including Directive 2003/30/EC), the departure of the EU from the biofuel support policy in 2011 significantly disturbed the functioning of this sector. The EU partially resigned from the use of bioethanol. The promotion of biofuels, esters and bioethanol is to be completed by 2030.

Chances of meeting the targets set by the European Union are currently being sought mostly in products resulting from the process of co-hydrogenation and in biohydrogen produced using biomethane. Liquid bio-hydrocarbons formed as a result of co-hydrogenation have no limitations as to their mixing with conventional fuels (unlike methyl esters and bioethanol) and domestic fuel producers possess potential that could be employed in terms of launching HVO production using local installations intended to refine petroleum [36]. The liquid bio-hydrocarbon sector is one with great perspectives for the future, and is the only one with a rising value. However, its production capacity is currently at the initial stage of development. It is thus similar to biomethane, which is currently used in marginal quantities. However, taking into account the potential of the raw materials from which it can be produced and which are eligible for assignment to the advanced biofuel category, it gives rise to high hopes.

The results of this research may be used primarily by politicians and producers to ensure the achievement of the indicators set by the EU. Therefore, it is important to monitor the market on an ongoing basis and draw conclusions about the effect of legal and political conditions on the achieved indicators. This allows people to verify current legislation and modify or implement new solutions, which will allow them to achieve the set goals and avoid paying penalties. For scientists, this is an indication of what methods have been used to calculate the value of the sector and may be an impulse for possible modifications of the methods used. 


\section{Limitations}

Limitations, in terms of development of the biocomponent sector, result mostly from legal and environmental (ecological) regulations. The emergence of new legal conditions 2009/28/EC and a maximum of $7 \%$ in the fuel structure for bioethanol and esters are the main causes of problems in the Polish fuel industry. The legal and political landscape decides whether or not to support individual biofuel sectors. $\mathrm{CO}_{2}$ emission reduction on the basis of biocomponents is low in Poland; hence, there are problems with meeting the requirements stemming from NIT. However, the electromobility sector will continue to develop, using also the mechanical engineering knowledge to construct innovative engines with new mechanical and technical parameters, and all those activities will have an effect on $\mathrm{CO}_{2}$ emission reductions if electric energy is generated with raw materials produced from renewable (zero-emission) sources, rather than with fossil fuels (e.g., coal).

Author Contributions: Conceptualization, A.K., J.M.-S., and P.F.B.; Methodology, A.K. and J.M.-S.; Software, E.G.; Validation, P.F.B., A.K. and E.G.; Formal Analysis, A.K. and P.F.B.; Investigation, A.K., P.F.B., E.G. and J.M.-S.; Resources, P.F.B., E.G. and J.M.-S.; Data Curation, A.K.; Writing-Original Draft Preparation, J.M.-S. and P.F.B.; Writing-Review \& Editing, P.F.B.; E.G.; Visualization, P.F.B.; Supervision, A.K. and P.F.B.; Project Administration, A.K. and P.F.B. All authors have read and agreed to the published version of the manuscript.

Funding: The research and APC was funded by Warsaw University of Life Sciences (Institute of Mechanical Engineering).

Conflicts of Interest: The authors declare no conflict of interests.

\section{References}

1. Masjuki, H.M.; Kalam, M.A. An Overview of Biofuel as a Renewable Energy Source: Development and Challenges. Procedia Eng. 2013, 56, 53. [CrossRef]

2. Pietrzak, K.; Pietrzak, O. Environmental Effects of Electromobility in a Sustainable Urban Public Transport. Sustainability 2020, 12, 1052. [CrossRef]

3. Susmozas, A.; Martín-Sampedro, R.; Ibarra, D.; Eugenio, M.E.; Iglesias, R.; Manzanares, P.; Moreno, A.D. Process Strategies for the Transition of $1 G$ to Advanced Bioethanol Production. Processes 2020, 8, 1310. [CrossRef]

4. European Environment Agency (EEA). Transport. Available online: www.eea.europa.eu/pl/themes/transport/ intro (accessed on 3 October 2020).

5. Klimat dla Polski Polska dla Klimatu 1988-2018-2050, R. Jeszke, Ed. (Climate for Poland Poland for the Climate 1988-2018-2050). Available online: https://cop24.gov.pl/fileadmin/user_upload/files/1._Klimat-dlaPolski-Polska-dla-Klimatu_PL.pdf (accessed on 27 November 2020).

6. Giunta, M.; Lo Bosco, D.; Leonardi, G.; Scopelliti, F. Estimation of Gas and Dust Emissions in Construction Sites of a Motorway Project. Sustainability 2019, 11, 7218. [CrossRef]

7. Praticò, F.G.; Giunta, M.; Mistretta, M.; Gulotta, T.M. Energy and Environmental Life Cycle Assessment of Sustainable Pavement Materials and Technologies for Urban Roads. Sustainability 2020, 12, 704. [CrossRef]

8. Ciucci, M. Energia ze źródeł Odnawialnych. (Energy from renewable sources). Available online: www. europarl.europa.eu/factsheets/pl/sheet/70/energia-ze-zrodel-odnawialnych (accessed on 3 October 2020).

9. Porter, M.E. Competitive strategy. Meas. Bus. Excell. 1997, 1, 12-17. [CrossRef]

10. Gradziuk, P.; Jendrzejewski, B. Wyzwania dla sektora biopaliw w kontekście polityki klimatyczno-energetycznej Unii Europejskiej. (Challenges for the biofuel sector in the context of the European Union's climate and energy policy). Rocz. Nauk. Stowarzyszenia Ekon. Rol. Agrobiz. 2007, 2, $58-65$.

11. Kupczyk, A.; Borowski, P.; Powałka, M.; Ruciński, D. Biopaliwa Transportowe w Polsce. Stan Aktualny $i$ Perspektywy; Transport Biofuels in Poland. Current Status And Prospects; Oficyna Wydawniczo-Poligraficzna ADAM: Warsaw Poland, 2011.

12. Borowski, P.; Gawron, J.; Golisz, E.; Kupczyk, A.; Piechocki, J.; Powałka, M.; Tucki, K. Wpływ Redukcji Emisji $\mathrm{CO}_{2}$ na Funkcjonowanie Sektorów Biopaliw Transportowych w Polsce. Wyd; Impact of $\mathrm{CO}_{2}$ Emission Reduction on the Operation of the Transport Biofuels Sector in Poland; WEMA: Warsaw, Poland, 2014. 
13. EC. Directive 2009/28/EC of the European Parliament and of the Council of 23 April 2009 on the Promotion of the Use of Energy from Renewable Sources and Amending and Subsequently Repealing Directives 2001/77/EC and 2003/30/EC; European Commission: Brussels, Belgium, 2009.

14. EC. Directive (EU) 2015/1513 of the European Parliament and of the Council of 9 September 2015 Amending Directive 98/70/EC Relating to the Quality of Petrol and Diesel Fuels and Amending Directive 2009/28/EC on the Promotion of the Use of Energy from Renewable Sources; European Commission: Brussels, Belgium, 2015.

15. EC. Directive (EU) 2018/2001 of the European Parliament and of the Council of 11 December 2018 on the Promotion of the Use of Energy from Renewable Sources; European Commission: Brussels, Belgium, 2018.

16. Subramaniam, Y.; Masron, T.A.; Azman, N.H.N. Biofuels, environmental sustainability, and food security: A review of 51 countries. Energy Res. Soc. Sci. 2020, 68, 101549. [CrossRef]

17. Mączyńska, J.; Krzywonos, M.; Kupczyk, A.; Tucki, K.; Sikora, M.; Pińkowska, H.; Bączyk, A.; Wielewska, I. Production and use of biofuels for transport in Poland and Brazil-The case of bioethanol. Fuel 2019, 241, 989-996. [CrossRef]

18. Koizumi, T. Biofuels and food security. Renew. Sustain. Energy Rev. 2015, 52, 829-841. [CrossRef]

19. Kim, E.J.; Kim, S.; Choi, H.-G.; Han, S.J. Co-production of biodiesel and bioethanol using psychrophilic microalga Chlamydomonas sp. KNM0029C isolated from Arctic sea ice. Biotechnol. Biofuels 2020, 13, 1-13. [CrossRef]

20. Zalega, K. Znaczenie biopaliw i systemu ich certyfikacji-Polityka energetyczna i klimatyczna Unii Europejskiej (Importance of biofuels and their certification system - European Union energy and climate policy). Kontrola Państwowa 2017, 62, 40-60.

21. Ustawa z Dnia 25 Sierpnia 2006 r. o Biokomponentach i Biopaliwach Ciekłych (Dz.U. 2006 nr 169 poz. 1199, z późn. zm). (The Act of August 25, 2006 on Biocomponents and Liquid Biofuels). Available online: http://isap.sejm.gov.pl/isap.nsf/DocDetails.xsp?id=wdu20061691199 (accessed on 3 October 2020).

22. Energy Regulatory Office. Wysokość Narodowych Celów Wskaźnikowych Ustalona na Lata 2017-2020 (The amount of the National Indicative Targets Established for the Years 2017-2020). Available online: https:/www.ure.gov.pl/pl/urzad/informacje-ogolne/aktualnosci/7017,Wysokosc-NarodowychCelow-Wskaznikowych-ustalona-na-lata-2017-2020.html (accessed on 3 October 2020).

23. Uzasadnienie do Projektu Ustawy o Zmianie Ustawy o Biokomponentach i Biopaliwach Ciekłych Oraz Uzasadnienie do Projektu Niektórych Innych Ustaw z 2019 r. (DKPL.WK.10.2.77.2019.AMU(8)) (Justification to the Draft Act Amending the Act on Biocomponents and Liquid Biofuels and Justification to the Draft Certain Other Acts of 2019). Available online: http://orka.sejm.gov.pl/Druki8ka.nsf/Projekty/8-020-13922019/\$file/8-020-1392-2019.pdf (accessed on 3 October 2020).

24. Giuntoli, J. Advanced Biofuel Policies in Select UE Member States: 2018 Update. International council on Clean Transportation. Available online: https://theicct.org/sites/default/files/publications/Advanced_biofuel_ policy_eu_update_20181130.pdf (accessed on 6 November 2019).

25. Energia z Zasobów Odnawialnych. Gdańska Infrastruktura Wodociagowo-Kanalizacyjna Sp. z o.o. (Energy from Renewable Sources). Available online: http://www.giwk.pl/files/21/219/245/podrecznik.pdf (accessed on 4 October 2020).

26. Rimkus, A.; Stravinskas, S.; Matijošius, J. Comparative Study on the Energetic and Ecologic Parameters of Dual Fuels (Diesel-NG and HVO-Biogas) and Conventional Diesel Fuel in a CI Engine. Appl. Sci. 2020, 10, 359. [CrossRef]

27. Krajowy Ośrodek Wsparcia Rolnictwa. Dane Dotyczące Ilości Biokomponentów Wytworzonych, a Następnie Rozporządzonych Przez Dokonanie Jakiejkolwiek Czynności Prawnej lub Faktycznej, Lub Przeznaczonych do Wytworzenia Paliw Ciekłych lub Biopaliw Ciekłych Przez Wytwórców, z Uwzględnieniem Podstawowych Surowców Użytych do ich Wytworzenia (I-IV Kwartał 2019). National Agricultural Support Center. Data on the amount of Biocomponents Produced and then Disposed of by any Legal or Actual Act, or Intended for the Production of Liquid Fuels or Liquid Biofuels by Producers, including the Basic Raw Materials Used for Their Production (Q1-Q4 2019). 2020. Available online: https://bip.kowr.gov.pl/informacje-publiczne/ odnawialne-zrodla-energii/informacje-dotyczace-rynku-biokomponentow (accessed on 4 October 2020).

28. KOWR. Dane Dotyczące Wytwarzania Biokomponentów za Lata 2015-2020. National Agricultural Support Center. Data on the Production of Biocomponents for 2015-2020. 2020. Available online: https://bip.kowr.gov.pl/informacje-publiczne/odnawialne-zrodla-energii/informacje-dotyczacerynku-biokomponentow (accessed on 4 October 2020). 
29. Krajowy Ośrodek Wsparcia Rolnictwa. Rejestr wytwórców (Stan na 25.09.2020 r.). National Agricultural Support Center. Data on the Production of Biocomponents for 2015-2020. 2020. Available online: https://www. kowr.gov.pl/uploads/pliki/DI/Biokomponenty_i_biopaliwa/W/Rejestr_wytworcow_2020.09.25.pdf (accessed on 4 October 2020).

30. Mączyńska, J.; Kupczyk, A.; Rutkowski, D.; Tucki, K. Aktualne problemy sektorów biokomponentów i biopaliw ciekłych w Polsce (Current problems of biocomponents and liquid biofuels sectors in Poland). Gospod. Mater. Logistyka 2019, 2, 23-27. [CrossRef]

31. Golisz, E.; Kupczyk, A.; Mączyńska, J. Biopaliwa ciekłe w świetle dyrektywy 2018/2001 w sprawie promowania stosowania energii ze źródeł odnawialnych (Liquid biofuels in the light of Directive (EU) 2018/2001 on the promotion of the use of energy from renewable sources). Gospod. Mater. Logistyka 2019, 6, 20-25.

32. GUS. Energia ze Źródeł Odnawialnych W 2014 Roku; Energy from Renewable Sources in 2014; GUS: Warsaw, Poland, 2015.

33. GUS. Energia ze Źródeł Odnawialnych W 2016 Roku; Energy from Renewable Sources in 2016; GUS: Warsaw, Poland, 2017.

34. GUS. Energia ze Źródet Odnawialnych W 2018 Roku; Energy from Renewable Sources in 2018; GUS: Warsaw, Poland, 2019.

35. Eurostat. Share of Energy from Renewable Sources in Transport, 2004-2018. Available online: https:/ec.europa.eu/eurostat/statistics-explained/index.php?title=File:Share_of_energy_from_renewable_ sources_in_transport,_2004-2018_(\%25_of_gross_final_energy_consumption).png (accessed on 3 October 2020).

36. Polska Izba Paliw Płynnych. Nowelizacja Ustawy o Biopaliwach (Polish Chamber of Liquid Fuels Amendment to the act on biofuels). Available online: http://paliwa.pl/strona-startowa/archiwum/nowelizacja-ustawy-obiopaliwach (accessed on 4 October 2020).

37. Energy Regulatory Office Wykaz Podmiotów, które są Zobowiązane do Realizacji Narodowego Celu Wskaźnikowego (List of Entities that are Required to achieve the National Indicative Target). Available online: https://rejestry.ure.gov.pl/o/17 (accessed on 4 October 2020).

38. CMS. Nowelizacja Ustawy o Biokomponentach i Biopaliwach—Sposób na Kryzys Paliwowy Czy też Szansa na Nowe Inwestycje? Amendment to the act on Biocomponents and Biofuels-A Way to Deal with the Fuel Crisis or a Chance for New Investments? Available online: https://www.cire.pl/item,184194, 14,0,0,0,0,0,nowelizacja-ustawy-o-biokomponentach-i-biopaliwach---sposob-na-kryzys-paliwowy-czytez-szansa-na-nowe-inwestycje.html (accessed on 4 October 2020).

39. Dawid, H.; Reimann, M. Evaluating Market Attractiveness: Individual Incentives Versus Industry Profitability. Comput. Econ. 2005, 24, 321-355. [CrossRef]

40. Borowski, P.F. New Technologies and Innovative Solutions in the Development Strategies of Energy Enterprises. High Tech Innov. J. 2020, 1, 39-58. [CrossRef]

41. Dzwigol, H.; Aleinikova, O.; Umanska, Y.; Shmygol, N.; Pushak, Y. An entrepreneurship model for assessing the investment attractiveness of regions. J. Entrep. Educ. 2019, 22, 1-7.

42. Zykiene, I.; Snieška, V.; Bruneckiene, J.; Burksaitiene, D. Assessment of regions using an index for a location's attractiveness for business development. Econ. Res. Ekon. Istraz. 2020, 1-19. [CrossRef]

43. Golisz, E.; Kupczyk, A. Stan aktualny i perspektywy rozwoju sektora biopaliw transportowych w Polsce (Current state and development prospects for the transport biofuels sector in Poland). Gospod. Mater. Logistyka 2016, 3, 32-40.

44. Golisz, E.; Samson-Bręk, I.; Borowski, P.; Kupczyk, A. Konieczne zmiany w sektorze biopaliw transportowych w Polsce (Necessary Changes in the Market of Biofuels Transport in Poland). Gospod. Mater. Logistyka 2013, 11, 2-12.

45. Sikora, M. Aktualny stan i atrakcyjność sektorów biopaliw w Polsce. Cz. 2 (Current state and attractiveness of the biofuel sectors in Poland. Part 2). Przemyst Ferment. I Owocowo Warzywny 2016, 1, 27-29. [CrossRef]

46. Kupczyk, A.; Mączyńska, J.; Sikora, M.; Gawron, J. Identyfikacja obecnego stanu oraz atrakcyjność sektorów biopaliw transportowych w Polsce (Identification of the current state and the attractiveness of the transport biofuel sectors in Poland). Rocz. Nauk. Stowarzyszenia Ekon. Rol. Agrobiz. 2017, 19, 139-144.

47. Borowski, P.F. Zonal and Nodal Models of Energy Market in European Union. Energies 2020, $13,4182$. [CrossRef]

48. Gallo, M.; Marinelli, M. Sustainable Mobility: A Review of Possible Actions and Policies. Sustainability 2020, 12, 7499. [CrossRef] 
49. Sierpiński, G.; Staniek, M.; Kłos, M.J. Decision Making Support for Local Authorities Choosing the Method for Siting of In-City EV Charging Stations. Energies 2020, 13, 4682. [CrossRef]

50. Kupczyk, A.; Mączyńska, J.; Redlarski, G.; Tucki, K.; Bączyk, A.; Rutkowski, D. Selected Aspects of Biofuels Market and the Electromobility Development in Poland: Current Trends and Forecasting Changes. Appl. Sci. 2019, 9, 254. [CrossRef]

51. Razmjoo, A.; Kaigutha, L.G.; Rad, M.V.; Marzband, M.; Davarpanah, A.; Denai, M. A Technical analysis investigating energy sustainability utilizing reliable renewable energy sources to reduce $\mathrm{CO}_{2}$ emissions in a high potential area. Renew. Energy 2020, 164, 46-57. [CrossRef]

52. Tsilingiridis, G.; Sidiropoulos, C.; Pentaliotis, A. Reduction of air pollutant emissions using renewable energy sources for power generation in Cyprus. Renew. Energy 2011, 36, 3292-3296. [CrossRef]

53. Lorenzi, G.; Baptista, P. Promotion of renewable energy sources in the Portuguese transport sector: A scenario analysis. J. Clean. Prod. 2018, 186, 918-932. [CrossRef]

54. Borowski, P.F. Bamboo as an innovative material for many branches of world industry, Annals of Warsaw University of Life Sciences-SGGW. For. Wood Technol. 2019, 107, 13-18. [CrossRef]

55. Borowski, P.F. Nexus between water, energy, food and climate change as challenges facing the modern global, European and Polish economy. AIMS Geosci. 2020, 6, 397-421. [CrossRef]

56. Rządowy Projekt Ustawy o Zmianie Ustawy o Biokomponentach i Biopaliwach Ciekłych Oraz Niektórych Innych Ustaw (A Government Bill to Amend the Act on Biocomponents and Liquid Biofuels and Certain Other Acts). Available online: https://www.sejm.gov.pl/Sejm8.nsf/PrzebiegProc.xsp?nr=3626 (accessed on 4 October 2020).

57. WysokieNapiecie.pl. Zmiany w Biopaliwach Nie Wprowadzą Rewolucji na Stacjach (Changes in biofuels will not revolutionize the petrol stations). Available online: https://wysokienapiecie.pl/21296-zmiany-wbiopaliwach-nie-wprowadza-rewolucji-na-stacjach/ (accessed on 4 October 2020).

58. Sawicki, B. Etanol i współuwodornienie są szansą na zwiększenie udziału biopaliw w Polsce (Ethanol and co-hydrogenation are an opportunity to increase the share of biofuels in Poland). Available online: https: //biznesalert.pl/bioetanol-wodor-biopaliwa-polska-zwiekszenie-energetyka/ (accessed on 4 October 2020).

Publisher's Note: MDPI stays neutral with regard to jurisdictional claims in published maps and institutional affiliations.

(C) 2020 by the authors. Licensee MDPI, Basel, Switzerland. This article is an open access article distributed under the terms and conditions of the Creative Commons Attribution (CC BY) license (http://creativecommons.org/licenses/by/4.0/). 